\title{
Effects of nitrogen availability on the growth of native grasses exotic weeds
}

\author{
PETRA N. LOWE, WILLIAM K. LAUENROTH, AND INGRID C. BURKE
}

Authors are Research Associate, Shortgrass Steppe Long Term Ecological Research Project, Department of Forest Sciences, Colorado State University, Fort Collins, Colorado 80523, Professor, Rangeland Ecosystem Science Department, Colorado State University, Fort Collins, Colo. 80523, Professor Department of Forest Sciences, Colorado State University, Fort Collins, Colo. 80523 respectively. At the time of the research, senior author was graduate research assistant, Rangeland Ecosystem Science Department, Colorado State University, Fort Collins, Colo.

\begin{abstract}
Many studies have shown that high nitrogen availability encourages the community dominance of exotic, weedy species. Other researchers have attempted to reduce existing exotic species infestations by reducing soil nitrogen availability. We tested the hypothesis that exotic weeds and native species differ in their response to nitrogen availability, predicting that the exotics would have a much more positive response than the natives at high nitrogen levels but that natives would better tolerate low nitrogen levels. To test this hypothesis, we conducted a greenhouse experiment investigating the aboveground biomass, belowground biomass, height, and aboveground tissue nitrogen concentration response of 2 North American native plant species, blue grama (Bouteloua gracilis H.B.K. Lag.) and western wheatgrass (Pascopyrum smithii (Rybd.) A. Love), and 4 exotic species, cheatgrass (Bromus tectorum $\mathbf{L}$.), leafy spurge (Euphorbia esula L.), Canada thistle (Cirsium arvense L.), and Russian knapweed (Centaurea repens $\mathrm{L}$.), to 5 levels of nitrogen availability, $0 \mathrm{~g}$ $\mathrm{N} / \mathrm{m}^{2}, 1 \mathrm{~g} \mathrm{~N} / \mathrm{m}^{2}, 4 \mathrm{~g} \mathrm{~N} / \mathrm{m}^{2}, 7 \mathrm{~g} \mathrm{~N} / \mathrm{m}^{2}$, and $10 \mathrm{~g} \mathrm{~N} / \mathrm{m}^{2}$. We grew single individuals of each species from seed in 3 liter pots in the greenhouse for $\mathbf{7 5}$ days. The exotics and natives did differ in their response to nitrogen availability, but not in the predicted manner. The exotics did not have a more positive response to nitrogen availability than the native species, and the species with the poorest response was an exotic. There were no differences between the exotic and native species at any level of nitrogen availability in root:shoot ratios, total biomass, or percent leaf tissue nitrogen, but the native species as a group gained more height than the exotics at every level of nitrogen availability. Our data do not show a generalizable relationship between exotic or native plant groups and growth response to nitrogen.
\end{abstract}

Key Words: nutrient response, Bromus tectorum, Cirsium arvense, Centaurea repens, Euphorbia esula, greenhouse

Non-native, invasive weed species are theorized to share a host of specific life history traits that contribute to their success as invasives; one of those characteristics is a rapid growth response to nutrient enrichment (Grime 1977, Baker 1986). Conversely, fast growing plant species, many but not all of which are exotic weeds, are thought to fare poorly under low nutrient conditions

Research was funded by National Science Foundation Grant (DEB-9707296)

Manuscript accepted 14 Feb. 2001.
Resumen

Muchos estudios han demostrado que la alta disponibilidad de nitrógeno promueve el dominio de la comunidad por especies de plantas exóticas y malezas. Otros investigadores han intentado reducir la infestación de especies exóticas reduciendo la disponibilidad de nitrógeno del suelo. Probamos la hipótesis de que las malezas exóticas y las especies nativas difieren en su respuesta a la disponibilidad de nitrógeno, prediciendo que las exóticas tendrían una respuesta mucho mas positiva que las nativas a los altos niveles de nitrógeno, pero que las nativas tolerarían mejor los bajos niveles de nitrógeno. Para probar esta hipótesis se condujo un experimento en invernadero investigando la respuesta de la biomasa aérea y subterránea, la altura de planta y la concentración de nitrógeno en los tejidos aéreos de dos especies nativas de Norte América "Blue grama" (Bouteloua gracilis H.B.K. Lag.) y "Western wheatgrass" (Pascopyrum smithii (Rybd.) A. Love) y cuatro especies exóticas "Cheatgrass" (Bromus tectorum L.), "Leafy spurge" (Euphorbia esula L.), "Canada thistle" (Cirsium arvense L.) y "Russian knapweed" (Centaurea repens L.) a 5 niveles disponibilidad de nitrógeno: $0 \mathrm{~g} \mathrm{~N} / \mathrm{m}^{2}, 1 \mathrm{~g} \mathrm{~N} / \mathrm{m}^{2}, 4$ $\mathrm{g} \mathrm{N} / \mathrm{m}^{2}, 7 \mathrm{~g} \mathrm{~N} / \mathrm{m}^{2}$ y10 g N$/ \mathrm{m}^{2}$. Plantas individuales de cada especie provenientes de semilla crecieron durante 75 días en 31 macetas en el invernadero. Las exóticas y nativas difirieron en su respuesta a la disponibilidad de nitrógeno, pero no en la manera predicha. Las exóticas no tuvieron una respuesta mas positiva a la disponibilidad de nitrógeno que la nativas y la especie con la respuesta mas pobre fue una exótica. En ningún nivel de disponibilidad de nitrógeno se detectaron diferencias entre las especies exóticas y nativas respecto a la relación tallo:raíz, biomasa total o porcentaje de nitrógeno en el tejido foliar, pero las especies nativas como grupo ganaron mas altura que las exóticas en cada nivel de disponibilidad de nitrógeno. Nuestros datos no muestran una relación generalizable entre grupos de plantas exóticas y nativas y la respuesta del crecimiento al nitrógeno.

(Grime 1977, Chapin 1980, Shipley and Keddy 1988, Carson and Pickett 1990). The spread and persistence of invasive exotic weeds is of major concern to both land owners and conservationists as exotic plant invasion can reduce biodiversity (Huston 1994) and alter ecosystem function (Vitousek 1986).

High nitrogen availability has been shown to encourage the spread and dominance of exotic invasive weeds (Hobbs and Atkins 1988, Huenneke et al. 1990, Milchunas and Lauenroth 1995). Other researchers have attempted to reduce exotic species by reducing nitrogen availability, hypothesizing that native 
species have a competitive advantage over exotics under low nitrogen conditions (McLendon and Redente 1992, Wilson and Gerry 1995, Morghan and Seastedt 1999, Paschke et al. 2000). Several exotic species, such as cheatgrass (Bromus tectorum L.), leafy spurge (Euphorbia esula L.), Canada thistle (Cirsium arvense L.), and Russian knapweed (Centaurea repens L.), have become of particular concern in western rangelands of the United States because of their aggressive invasion of large areas. Empirically testing the response of these species to varying nitrogen levels can help predict the impact of nitrogen additions or reductions on systems where these noxious weeds occur.

The objective of this study was to test the hypothesis that fast growing exotic weeds have a different response to both low and high levels of nitrogen availability than native species. We predicted the exotic species would have a greater response than the natives to nitrogen at high levels of availability, but the natives would better ability to tolerate the low levels of nitrogen. Additionally, we tested the common assumption that exotic species are strongly responsive to nitrogen inputs.

\section{Methods}

We set up the experiment in the greenhouse as a completely randomized design with 6 species at 5 levels of nitrogen availability. We had 5 replicates of each species at each level of nitrogen availability for a total of 150 pots. Two of the plants were native species and 4 were invasive, exotic species. The native species were blue grama (Bouteloua gracilis H.B.K. Lag.) a warm season perennial grass, and western wheatgrass (Pascopyrum smithii (Rydb) A. Love), a cool season perennial grass. Blue grama was chosen because it dominates a large portion of the shortgrass steppe, an ecosystem that has not been significantly invaded by exotic weeds (Kotanen et al. 1998). Western wheatgrass is a native species that has some weedy characteristics (sensu Baker 1986), for example, it grows readily in disturbed areas such as roadsides (Stubbendieck et al. 1981). The exotic, invasive weed species selected for study were cheatgrass, (Bromus tectorum), leafy spurge (Euphorbia esula), Canada thistle (Cirsium arvense), and Russian knapweed (Centaurea repens). Blue grama and western wheatgrass seeds were obtained from Pawnee Buttes Seed Inc. (Greeley, Colo.). Cheatgrass seeds were collected by hand at the Central Plains Experimental Range (CPER, $40^{\circ} 49^{\prime} \mathrm{N}$ latitude, $107^{\circ} 46^{\prime} \mathrm{W}$ longitude), which is $61 \mathrm{~km}$ northeast of Fort Collins, Colo., USA. The seeds for the other exotic species were collected from open field sites in Fort Collins, Colo.

We sowed 10 seeds of each species into each of $25,15-\mathrm{cm} \times 16.5-\mathrm{cm}$ plastic pots with a substrate of $60 \%$ vermiculite, $40 \%$ washed sand by volume and a surface area of $191 \mathrm{~cm}^{2}$. Ten days after first emergence, we thinned the seedlings to 1 plant per pot.

A nitrogen gradient was established with 5 levels of nitrogen the equivalent of $0 \mathrm{~g} \mathrm{~N} / \mathrm{m}^{2}, 1 \mathrm{~g} \mathrm{~N} / \mathrm{m}^{2}, 4 \mathrm{~g} \mathrm{~N} / \mathrm{m}^{2}, 7 \mathrm{~g} \mathrm{~N} / \mathrm{m}^{2}$, and $10 \mathrm{~g} \mathrm{~N} / \mathrm{m}^{2}$. Nitrogen availability across the Great Plains of the United States, where the species tested here would grow, and potentially compete, ranges from $1.5 \mathrm{~g} / \mathrm{m}^{2}$ to $10.5 \mathrm{~g} / \mathrm{m}^{2}$ (Burke et al. 1997). We applied the nitrogen treatments as a solution of ammonium nitrate in stages: $10 \%$ of the total ammonium nitrate application was applied on the $20^{\text {th }}$ day after germination, and every 2 weeks thereafter we added dosages of $25 \%, 30 \%$, $20 \%$, and $5 \%$. We applied all micro- and macro-nutrients, except nitrogen, to the pots with a modified Hoagland's solution at a rate of $100 \mathrm{ml}$ every week. We maintained the pots near field capacity by watering every day or every other day, depending upon need. We maintained the pots in an unshaded greenhouse from 8 July to 21 Sept. 1999, about 75 days.

At the end of the experiment, we harvested aboveground biomass by clipping each plant just above the root crown and drying the plant material at $55^{\circ} \mathrm{C}$ for 48 hours. We washed the root system of each plant carefully to remove as much of the potting material as possible. Root biomass is reported on an ash free basis. We measured plant height in centimeters for each plant at the end of the experiment, before biomass harvesting. We ground the dried aboveground material in a ball mill and analyzed a $0.1 \mathrm{~g}$ subsample for nitrogen content in a LECO CHN-1000 analyzer (St. Joseph, Mich.).

We analyzed the data in 2 ways. First,

Table 1. Regressions for 6 plant species of nitrogen availability versus aboveground biomass gain over 75 days when grown from seed in the greenhouse.

\begin{tabular}{lccccc}
\hline Species & Native/Exotic & Slope & Y-Intercept & $R^{2}$ & $n$ \\
\hline Cirsium arvense & Exotic & $0.417^{* \mathrm{a}}$ & 0.008 & 0.788 & 16 \\
Bromus tectorum & Exotic & $0.403^{* \mathrm{a}}$ & 0.190 & 0.905 & 23 \\
Bouteloua gracilis & Native & $0.375^{* \mathrm{a}}$ & 0.255 & 0.715 & 23 \\
Centaurea repens & Exotic & $0.264^{* \mathrm{~b}}$ & 0.019 & 0.880 & 21 \\
Pascopyrum smithii & Native & $0.227^{* \mathrm{~b}}$ & 0.285 & 0.667 & 21 \\
Euphorbia esula & Exotic & $0.044^{* \mathrm{c}}$ & 0.017 & 0.399 & 24 \\
\hline
\end{tabular}

Slopes significantly different from zero are indicated with $*(P=0.05)$. Slopes with the same letter are not significantly different at $\mathrm{P}=0.05$. we analyzed the aboveground biomass at the end of the experiment versus nitrogen availability using regression in SAS 1999 (SAS Institute, Cary, N.C.) to compare response slopes. Secondly, we used oneway analysis of variance utilizing a general linear model in SAS to determine differences between root:shoot ratios of the individual species at different nitrogen levels, and the differences between total biomass, height, and percent tissue nitrogen of the grouped average response of the 4 exotics and the 2 natives. We used Fisher's least significant difference (LSD) procedure $(\mathrm{P}=0.05)$ to compare all treatment means and slopes.

\section{Results}

There was a significant positive relationship between aboveground biomass and nitrogen availability for each species, but the responses differed significantly (Table 1). The most positive relationships were for the exotics Cirsium arvense and Bromus tectorum and the native Bouteloua gracilis. The species with the least positive relationship between aboveground biomass and nitrogen availability was the exotic Euphorbia esula.

Root:shoot ratios did not differ between species at different nitrogen levels, but did differ at different nitrogen levels for each species (Table 2). All species with the exception of Euphorbia esula showed a decrease in the root:shoot ratio with the increase of nitrogen availability from 0 to $1 \mathrm{~g} \mathrm{~N} / \mathrm{m}^{2}$, but showed no further decrease after this level.

There were no significant differences between total biomass gain at any level of nitrogen availability between native and exotic species (Fig. 1a). There were significant differences between natives and exotics for plant height, with the average height of the native species being significantly taller at every level of nitrogen availability than the average height of the exotics (Fig. 1b). Percent leaf nitrogen increased for both exotic and native 
TABLE 2. Mean root:shoot ratios ( \pm one standard error of the mean) of 6 different plant species grown at different nitrogen levels from seed in the greenhouse for 75 days.

\begin{tabular}{lccccrr}
\hline \hline $\begin{array}{l}\text { Nitrogen } \\
\text { Level }\end{array}$ & PASM & BOGR & BRTE $^{*}$ & CERE $^{*}$ & CIAR $^{*}$ & \multicolumn{1}{c}{ EUES $^{*}$} \\
\hline $0 \mathrm{~g} / \mathrm{m}^{2}$ & $8.8 \pm 3.1^{\mathrm{a}}$ & $13.8 \pm 4.9^{\mathrm{a}}$ & $9.5 \pm 3.8^{\mathrm{a}}$ & $20.5 \pm 10.2^{\mathrm{a}}$ & $11.6 \pm 8.3^{\mathrm{a}}$ & $6.67 \pm 2.7^{\mathrm{a}}$ \\
$1 \mathrm{~g} / \mathrm{m}^{2}$ & $4.9 \pm 3.9^{\mathrm{b}}$ & $2.03 \pm 0.9^{\mathrm{b}}$ & $3.4 \pm 1.6^{\mathrm{b}}$ & $3.5 \pm 1.2^{\mathrm{b}}$ & $1.9 \pm 0.4^{\mathrm{b}}$ & $2.43 \pm 1.0^{\mathrm{a}}$ \\
$4 \mathrm{~g} / \mathrm{m}^{2}$ & $0.76 \pm 0.1^{\mathrm{b}}$ & $0.99 \pm 0.08^{\mathrm{b}}$ & $1.4 \pm 0.3^{\mathrm{b}}$ & $0.43 \pm 0.08^{\mathrm{b}}$ & $0.73 \pm 0.3^{\mathrm{b}}$ & $4.5 \pm 2.6^{\mathrm{a}}$ \\
$7 \mathrm{~g} / \mathrm{m}^{2}$ & $0.79 \pm 0.09^{\mathrm{b}}$ & $0.95 \pm 0.7^{\mathrm{b}}$ & $0.70 \pm 0.1^{\mathrm{b}}$ & $0.50 \pm 0.04^{\mathrm{b}}$ & $0.57 \pm 0.03^{\mathrm{b}}$ & $2.67 \pm 1.0^{\mathrm{a}}$ \\
$10 \mathrm{~g} / \mathrm{m}^{2}$ & $1.02 \pm 0.3^{\mathrm{b}}$ & $0.44 \pm 0.1^{\mathrm{b}}$ & $0.70 \pm 0.1^{\mathrm{b}}$ & $0.45 \pm 0.08^{\mathrm{b}}$ & $0.38 \pm 0.02^{\mathrm{b}}$ & $2.8 \pm 1.6^{\mathrm{a}}$ \\
\hline
\end{tabular}

PASM=Pascopyrum smithii. $\mathrm{BOGR}=$ Bouteloua gracilis. $\mathrm{BRTE}=$ Bromus tectorum. $\mathrm{CERE}=$ Centaurea repens. CIAR=Cirsium arvense. EUES=Euphorbia esula. Means within the same column with the same letter are not significantly different at $\mathrm{P}=0.05$. ${ }^{*}$ Denotes an exotic species.

species as nitrogen availability increased but there were no significant differences between the percent leaf nitrogen of the exotic and native species at any level of nitrogen availability (Fig. 2).

\section{Discussion}

Our data support the hypothesis that exotic and native species differ in response to nitrogen availability, but not in the way we predicted. We predicted that the exotic species would have higher growth than the natives at high nitrogen levels, as both theoretical (Grime 1977, Baker 1986) and field studies have either predicted or shown this result (Huenneke et al. 1990, McLendon and Redente 1991, Milchunas and Lauenroth 1995). Conversely, we predicted that the native species would grow better than the exotics at low levels of nitrogen availability, as has been predicted by Chapin (1980) and shown by others (Wedin and Tilman 1990, Redente et al. 1992).

If our original prediction was correct, comparing the regression slopes of aboveground biomass to nitrogen availability (Table 1) should show the exotic species with more positive responses to nitrogen availability than natives; however, this did not occur. The responses were mixed, with the 2 native species having the same response to increasing nitrogen availability as 3 out of the 4 exotic species. Additionally, there were no differences in total biomass gain between averages of the 2 native species and the 4 exotic species at any level of nitrogen availability (Fig. 1a), and the average plant height of the native species had a greater response to increasing nitrogen availability than the exotics (Fig. 1b), which is very different from the predicted results.

We also tested the assumption that exotic species have a strong response to nitrogen inputs. Our data show that some exotics have a strong response to nitrogen inputs while others do not. The species with the weakest response was Euphorbia esula, a species that has invaded 3 million acres in 29 of the 50 states in the U.S. (Sheley and Petroff 1999). Growth response to nitrogen availability can not explain the competitive success of all exotics, other factors such as response to water availability, temperature, or her-

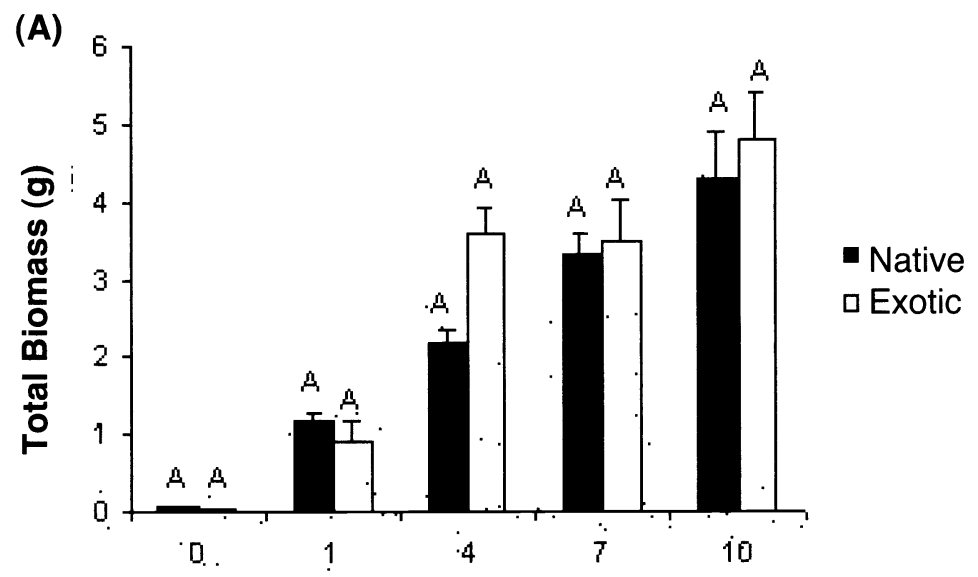

(B)

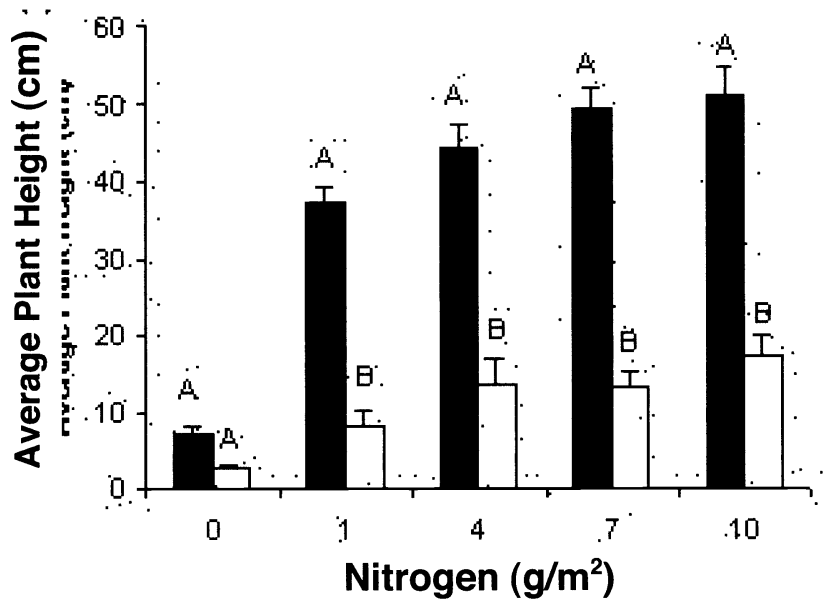

Fig. 1. Averaged total biomass gain (A) and plant height (B) response of 2 native species (Bouteloua gracilis and Pascopyrum smithii) and 4 exotic species (Bromus tectorum, Centaurea repens, Cirsium arvense, and Euphorbia esula) grown from seed in the greenhouse for 75 days, to a gradient in nitrogen availability. Error bars are one standard error of the mean. Bars with the same letter are not significantly different at $P=0.05$. 


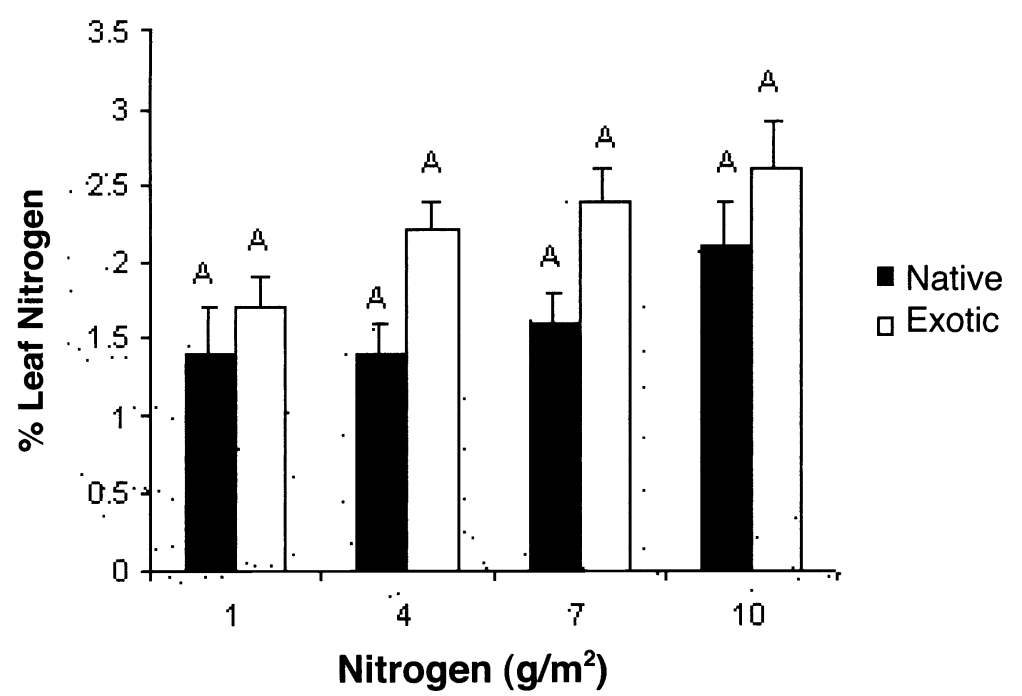

Fig. 2. Averaged \% leaf nitrogen response of 2 native species (Bouteloua gracilis and Pascopyrum smithii) and 4 exotic species (Bromus tectorum, Centaurea repens, Cirsium arvense, and Euphorbia esula) grown from seed in the greenhouse for $\mathbf{7 5}$ days, to a gradient in nitrogen availability. Error bars are one standard error of the mean. Bars with the same letter are not significantly different at $P=0.05$.

annuals and 3 shrubs to a gradient in nitrogen availability. They found that native species had a much stronger response to increasing nitrogen availability than predicted, showing a greater relative yield response than all 3 exotics in the study. Redente et al. (1992) grew 4 native species and 1 fast growing exotic species, Russian thistle [Salsola iberica (Sennen)], under 7 different nitrogen levels, and found the growth of Russian thistle was significantly reduced at low levels of available nitrogen while the slow growing native species performed comparatively better. We found no differences in the growth of the exotics and natives we tested at low nitrogen levels.

\section{Management Implications}

Several researchers have attempted, with varying levels of success, to reduce existing exotic weed populations by reducing nitrogen availability, hypothesizing that native species are better adapted to low nitrogen environments and therefore have a competitive advantage over exotics under low nitrogen conditions (McLendon and Redente 1992, Morgan 1994, Seastedt et al. 1996, Wilson and Gerry 1995, Morghan and Seastedt 1999). McLendon and Redente (1992) were successful in reducing the canopy cover of 2 fast growing exotic weeds, Russian thistle, and kochia (Kochia scoparia (L.) Schrad.) by reducing soil nitrogen content with the addition of sucrose to a disturbed sagebrush system in northwestern Colorado. By contrast, Seastedt et al. (1996) and
Morghan and Seastedt (1999) were unable to reduce the density of 2 exotic invasive plants, field alyssum (Alyssum minus (L.) Rothm.), and diffuse knapweed (Centaurea diffusa Lam.) when they reduced soil nitrogen with additions of sucrose and sawdust to a disturbed mixed grass community in Colorado. Restoration efforts attempting to reduce exotic weed species by reducing nitrogen availability rely on the differential responses of exotic and native species to nitrogen, specifically that exotic weed species will be at more of a disadvantage at low nitrogen levels than native species. Our results show, for the species tested, that there is no generalizable relationship between life history (weedy exotic versus non-weedy native) and growth response to nitrogen. From these results, we predict that the success of restoration efforts using nitrogen reduction to control exotic species may significantly depend on the species composition of the site to be treated.

\section{Literature Cited}

Baker, H.G. 1986. Patterns of plant invasion in North America. Pages 44-57 In: H.A. Mooney and J. A. Drake, editors. Ecology of biologically invasions of North America and Hawaii. Springer-Verlag, New York, N.Y., USA.

Burke, I. C. , Lauenroth, W. K., and W. J. Parton. 1997. Regional and temporal variation in net primary production and nitrogen mineralization in grasslands. Ecol. 78:1330-1340.

Carson, W.P. and S.T.A. Pickett. 1990. Role of resources and disturbance in the organization of an old-field community. Ecol. 71:226-238

Chapin, F.S. 1980. The mineral nutrition of wild plants. Ann. Rev. Ecol. Syst. 11:233-260.

Grime, J.P. 1977. Evidence for the existence of three primary strategies in plants and its relevance to ecological and evolutionary theory. Amer. Nat. 11:1169-1194.

Hobbs, R.J. and L. Atkins. 1988. Effect of disturbance and nutrient addition on native and introduced annuals in plant communities in the Western Australian wheatbelt. Aust. J. Ecol. 13:171-179.

Huenneke, L.F., S.P. Hamburg, R. Koide, H.A. Mooney, and P.M. Vitousek. 1990. Effects of soil resources on plant invasion and community structure in Californian serpentine grassland. Ecol. 71:478-491.

Huston, M.A. 1994. Biological Diversity: the coexistence of species in changing landscapes. Cambridge University Press, New York, N.Y

Kotanen, P. M., J. Bergelson, and D. L. Hazlett. 1998. Habitats of native and exotic plants in Colorado shortgrass steppe: a comparative approach. Can. J. Bot. 76:664-672.

McLendon, T. and E. F. Redente. 1991. Nitrogen and phosphorus effects on secondary succession dynamics on a semi-arid sagebrush site. Ecol. 72:2016-2024.

McLendon, T. and E.F. Redente. 1992. Effects of nitrogen limitation on species replacement dynamics during early secondary succession on a semiarid sagebrush site. Oecologio. 91:312-317.

Milchunas, D. G. and W. K. Lauenroth. 1995. Inertia in plant community structure:state changes after cessation of nutrient enrichment stress. Ecol. Appl. 5:452-458.

Morgan, J. 1994. Soil improvement: a little known technique holds potential for establishing prairie. Rest. Manage. Notes. 12(1):55-56.

Morghan, K.J. and T.R. Seastedt. 1999. Effects of soil nitrogen reduction on nonnative plants in restored grasslands. Rest. Ecol. 7(1):51-55.

Padgett, P.E. and E.B. Allen. 1999. Differential response to nitrogen fertilization in native shrubs and exotic annuals common to Mediterranean coastal sage scrub of California. Plant Ecol. 144:93-101.

Paschke, M. W., McLendon, T. and E. F. Redente. 2000. Nitrogen availability and old-field succession in a shortgrass steppe. Ecos. 3:144-158.

Redente, E.F., J.E. Friedlander, and T. McLendon. 1992. Response of early and late semiarid seral species to nitrogen and phosphorus gradients. Plant and Soil. 140:127-135.

SAS Institute. 1999. Software Release 8.00 . Cary, N.C.

Seastedt, T. R., Duffy, P. A., and Joshua N. Knight. 1996. Reverse fertilization experiment produces mixed results (Colorado). Rest. Mange. Notes. 14(1):64.

Sheley, R.L. and J.K. Petroff. 1999. Biology 
and Management of Noxious Rangeland Weeds. Oregon State University Press. Corvallis, Ore.

Shipley B. and P.A. Keddy. 1988. The relationship between relative growth rate and sensitivity to nutrient stress in twenty-eight species of emergent macrophytes. J. Ecol 76:1101-1110.
Stubbendieck, J., Hatch, S.L., and C.H. Butterfield. 1981. North American Range Plants. University of Neb. Press, Lincoln, Neb.

Vitousek, P.M. 1986. Biological invasions and ecosystem properties: can species make a difference? In: Mooney, H.A. and J. Drake (eds). Biological Invasions of North America and Hawaii. Springer. pp. 163-176.
Wedin, D. A. and D. Tilman. 1990. Species effects on nitrogen cycling: a test with perennial grasses. Oecologia. 84:433-441.

Wilson, S.D. and A.K. Gerry. 1995. Strategies for mixed-grass prairie restoration: herbicide, tilling, and nitrogen manipulation. Rest. Ecol. 3(4):290-298

\section{Position Announcement}

Montana State University seeks a dynamic and visionary administrator to lead teaching, research and extension programs in Animal \& Range Sciences. The Head will help determine the future direction of the department by leading the strategic planning process, hiring new faculty, and designing a new Animal \& Range Sciences building. Responsibilities include supervising faculty and staff, coordinating the promotion and tenure process, managing budgets and facilities, and representing the faculty to other departments in the College of Agriculture, the University, commodity groups, and government agencies. In addition, the Head will be expected to conduct a nationally recognized program in Animal and Range Sciences. Required: Earned Ph.D. in Animal Science, Range Science or a closely related field, and a record of outstanding scholarly accomplishment. Applicants must obtain complete vacancy announcement and application directions from www.montana.edu/level2/jobs.html or contact Joan Haynes, Search Secretary, Veterinary Molecular Biology Laboratory, P.O. Box 173610, Montana State University, Bozeman, MT 59717-3610 (phone 406-994-4705; FAX 406-994-4303; E-mail: jhaynes@montana.edu). Screening begins January 20, 2002. ADA/EO/AA/Vet. Pref. 